\title{
CARBON-FIBRE REINFORCED PLATES FOR PROBLEM FRACTURES
}

\author{
D. J. PEMBERTON, B. McKIBBIN, R. SAVAGE, K. TAYTON, D. STUART
}

From University of Wales College of Medicine, Cardiff

\begin{abstract}
We report our experience with carbon-fibre reinforced plastic (CFRP) plates in the management of 19 problem fractures complicated by either infection, nonunion, comminution or contamination. The combination offers secure fixation without inhibition of callus formation.
\end{abstract}

The use of so called stable osteosynthesis with the virtual elimination of interfragmentary movement by plates and screws is now well established in modern fracture treatment, by the use of AO-ASIF techniques.

Early restoration of function is the main advantage but because external callus formation is deliberately suppressed, healing is limited to direct remodelling of the bone ends. This is a slow process and the patient may therefore be dependent upon the support of the implant for a prolonged period (McKibbin 1978).

Normally, this may be of no great consequence but, in problem fractures in which the bone is of poor quality or there is severe comminution, it may be difficult to maintain complete stability for the required period. Dissection of comminuted fragments may cause devitalisation which further retards healing. Metal plates are notoriously prone to fatigue failure and will not support unstable conditions indefinitely.

In these circumstances the addition of bone graft will accelerate healing. Recently however, attempts have been made to deal with the problem by 'biological plating' in which the comminuted area is disturbed as little as possible. The fracture is bridged by a long plate which is more resistant to fatigue and allows the formation of some supporting callus (Müller et al 1991). This is a

D. J. Pemberton, FRCS, Senior Registrar B. McKibbin, MD, MS, FRCS, Professor

Department of Traumatic and Orthopaedic Surgery, University of Wales College of Medicine, Cardiff Royal Infirmary, Cardiff CF2 ISZ, South Glamorgan, Wales.

R. Savage, FRCS, FRCS Ed(Orth), Consultant Orthopaedic Surgeon

K. Tayton, FRCS, Consultant Orthopaedic Surgeon

Royal Gwent Hospital, Newport, Gwent NP9 2UB, Wales.

D. Stuart, FRCS, Consultant Orthopaedic Surgeon,

Nairobi Hospital, PO Box 43130, Nairobi, Kenya.

Correspondence should be sent to Mr D. J. Pemberton.

(C) 1992 British Editorial Society of Bone and Joint Surgery 0301-620X/92/1299\$2.00

J Bone Joint Surg [ Br] 1992; 74-B : 88-92. departure from the concept of rigid fixation and the results are awaited with interest.

Our approach has been to use a plate of an alternative material, carbon-fibre reinforced epoxy resin (CFRP), which is more resistant to fatigue than metal (Bradley, Hastings and Johnson-Nurse 1980). It is also sufficiently elastic to allow some movement, thereby encouraging the formation of bridging callus and accelerating the healing time.

Our initial experience with these plates in tibial fractures was reported (Tayton et al 1982); we have continued to use them for some fresh fractures. A total of about 300 plates have been used since 1979 , but their advantages are offset by their high cost, several times that of stainless steel, and by the fact that they cannot be contoured to bone, which limits their use in some anatomical situations.

However, cost is not a primary consideration in problem fractures when the fate of a limb depends on good management. The contouring problem can be overcome by preforming the plates.

We now describe our collective experience with CFRP plates in the treatment of problem fractures presenting to three different centres, Cardiff, Newport and Nairobi.

\section{MATERIAL AND METHODS}

The series includes 19 selected patients whose fractures presented particular problems resulting from poor bone quality, failed previous surgery, soft-tissue injury, severe comminution or infection. Details of these cases are given in Table $\mathrm{I}$.

Three different standard-sized plates were used: forearm plates measured $95 \times 9 \times 3 \mathrm{~mm}$, tibial plates were $135 \times 15 \times 5 \mathrm{~mm}$, femoral plates $135 \times 15 \times$ $7 \mathrm{~mm}$. They are manufactured commercially by hand laminating layers of carbon fibre with thermosetting epoxy resin (Orthodesign Ltd, Christchurch, England) as 
Table I. Summary of the 19 clinical cases

\begin{tabular}{|c|c|c|c|c|c|}
\hline Case & Age & $\because \because, \therefore, \cdots$ & $\begin{array}{l}\text { Bone } \\
\text { graft }\end{array}$ & $\begin{array}{l}\text { Weeks } \\
\text { to mion }\end{array}$ & Comment \\
\hline 1 & 16 & $\begin{array}{l}\text { Open tibial fracture with gross degloving, requiring split } \\
\text { skin grafts }\end{array}$ & No & 16 & \\
\hline 2 & 69 & $\begin{array}{l}\text { Open tibial fracture, plated elsewhere, primarily } \\
\text { infected requiring multiple sequestrectomies. Infected } \\
\text { nonunion with bone loss at two years }\end{array}$ & Yes & 18 & $\begin{array}{l}\text { Skin broke down over plate, but spontaneously } \\
\text { epithelialised over it }\end{array}$ \\
\hline 3 & 20 & Open tibial fracture with severe soft-tissue injury & No & 18 & \\
\hline 4 & 21 & Open tibial fracture with severe comminution & No & 17 & \\
\hline 5 & 45 & Open tibial fracture with $20 \%$ burns & Yes & 16 & Alcoholic, diabetic \\
\hline 6 & 39 & $\begin{array}{l}\text { Open ulnar fracture. AO plating elsewhere and wound } \\
\text { left open. Sinus and infected nonunion with bone loss }\end{array}$ & Yes & 13 & Sinus closed spontaneously after CFRP plating \\
\hline 7 & 31 & Open tibia with infected nonunion at six months & Yes & 32 & No recurrent infection \\
\hline 8 & 39 & $\begin{array}{l}\text { Open comminuted radial and ulnar fracture with severe } \\
\text { soft-tissue damage. AO plating initially. Infected } \\
\text { nonunion at } 11 \text { months }\end{array}$ & Yes & 28 & $\begin{array}{l}50 \% \text { pronation/supination obtained. Able to work } \\
\text { and write with this limb }\end{array}$ \\
\hline 9 & 63 & $\begin{array}{l}\text { Osteoporosis, nonunion of tibial fracture at eight } \\
\text { months, despite previous attempt at Phemister grafting }\end{array}$ & Yes & 40 & \\
\hline 10 & 37 & $\begin{array}{l}\text { Nonunion of radial and ulnar fractures despite six } \\
\text { attempts at fixation with grafting over } 12 \text { years }\end{array}$ & Yes & 28 & Radius united. Ulna failed to unite \\
\hline 11 & 64 & $\begin{array}{l}\text { One-armed patient with osteoporosis. Nonunion of } \\
\text { humerus following previous AO plating }\end{array}$ & Yes & 20 & $\begin{array}{l}\text { First CFRP plating complicated by screw loosening; } \\
\text { second attempt with nuts succeeded }\end{array}$ \\
\hline 12 & 69 & $\begin{array}{l}\text { Nonunion of tibial fracture at } 25 \text { months with chronic } \\
\text { osteomyelitis }\end{array}$ & Yes & 16 & No recurrent infection \\
\hline 13 & 26 & Nonunion of tibia at 11 months with persistent sinus & Yes & 20 & United despite intermittent discharge through sinus \\
\hline 14 & 48 & $\begin{array}{l}\text { Nonunion of tibial fracture through AO plate at nine } \\
\text { months }\end{array}$ & No & 12 & United despite low-grade infection \\
\hline 15 & 80 & Fracture of mid-shaft femur, bowed from old rickets & No & 16 & Anatomically could not be nailed \\
\hline 16 & 75 & Low supracondylar fractured femur, porotic bone & No & 12 & Contoured plate \\
\hline 17 & 31 & Open segmental fractures of humerus, radius and ulna & No & $\begin{array}{l}10 \\
20\end{array}$ & $\begin{array}{l}\text { Forearm } \\
\text { Humerus }\end{array}$ \\
\hline 18 & 23 & Basicervical and mid-shaft femoral fractures & No & 16 & $\begin{array}{l}\text { DHS to basicervical fracture, and CFRP plate to } \\
\text { diaphysis (Fig. 4) }\end{array}$ \\
\hline 19 & 36 & $\begin{array}{l}\text { Infected nonunion lower-third femoral fracture, } A O \text { nail } \\
\text { in situ }\end{array}$ & No & - & Fixation failed on weight-bearing \\
\hline
\end{tabular}

described by Bradley et al (1980) and reported in clinical practice by Tayton et al (1982). The plate used in case 16 was specially manufactured in pre-contoured form by the Department of Bioengineering, North Staffordshire Polytechnic. The remainder were straight. All the plates were secured with $2.7 \mathrm{~mm}$ and $3.5 \mathrm{~mm}$ AO cortical screws pretapped in the standard way; occasionally, locking nuts were also used.

If possible, the CFRP plates were fixed to the side of the bone under tension (Müller et al 1991) but if this was not possible, they were attached to the surface which gave the best anatomical reduction. No effort was made to compress the fractures and even moderately sized gaps were permitted. To allow interfragmentary movement every effort was made to prevent the screws crossing fracture gaps. If this was unavoidable in some commi- nuted fractures, the lag screw technique was deliberately not used.

Cancellous bone grafts from the iliac crest were applied to the fracture site in all ten cases of nonunion and in one fresh tibial fracture (case 5). No supplementary bone was used for any of the other fresh fractures.

Postoperative management was individually adjusted to the circumstances, but early mobilisation was usually advocated, with no external splintage. For lower limb fractures, partial or protected weight-bearing was encouraged as soon as possible after operation.

The plates were not removed after union unless there was a particular indication, which included the patient's request. When a plate was removed, its bed was carefully inspected for the presence of any carbon debris or reaction, and histological studies were carried out on the 


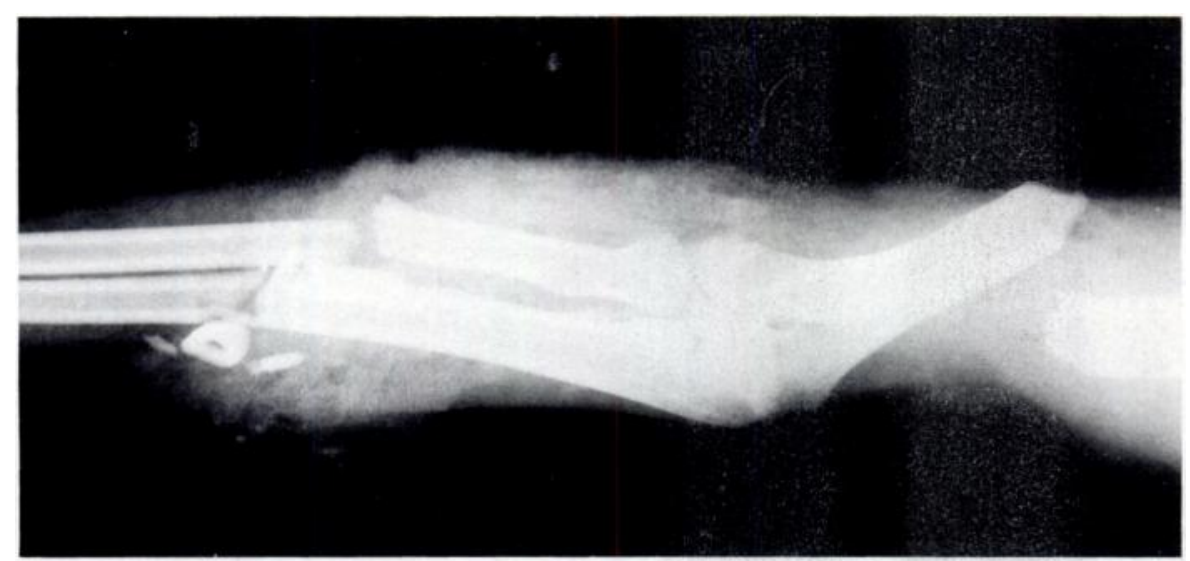

Fig. 1a

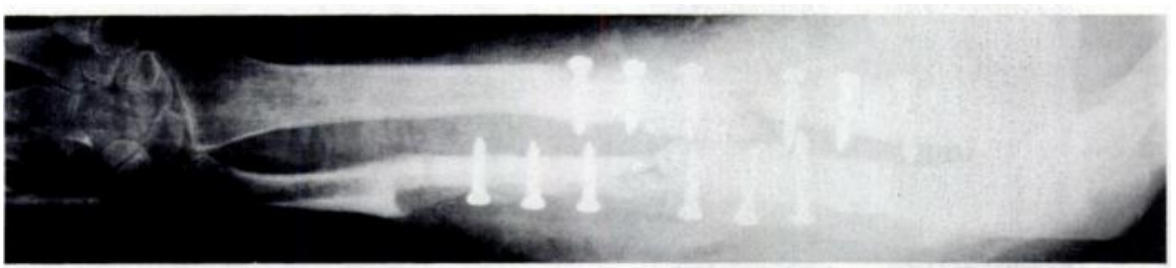

Fig. 1b

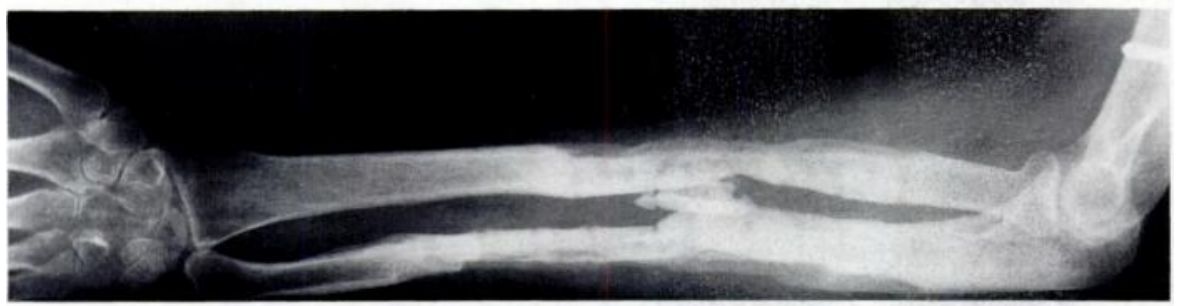

Fig. 1c

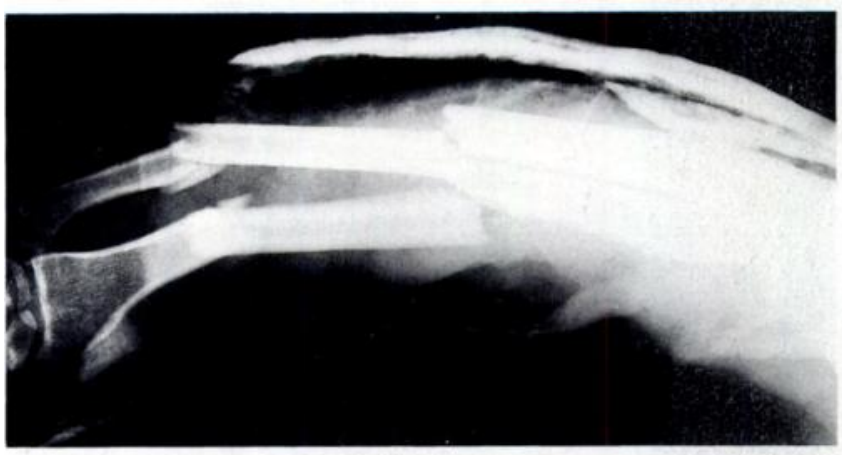

Fig. 2a

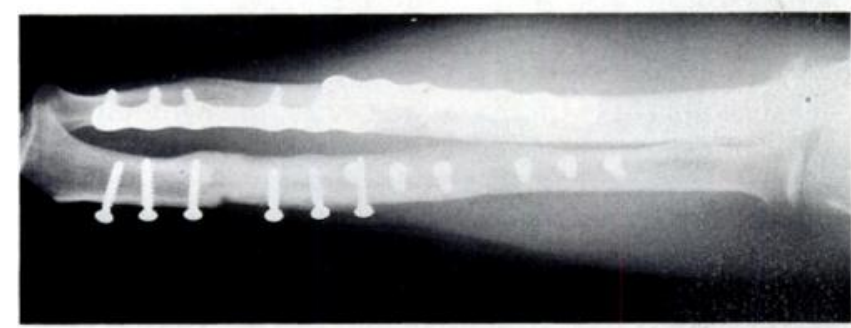

Fig. 2b

Figure 2a - Case 17. Open segmental fractures of the radius and ulna from an industrial accident, treated by CFRP plating to the radius, Sherman plating to the ulna. Figure $2 b-$ Good bridging callus 20 weeks after fixation. weeks.
Figure 1a - Case 8 . Severely comminuted and contaminated open fractures of the right radius and ulna, with a closed fracture of the humerus, in a 39-year-old woman struck by a bus. All fractures were initially treated elsewhere by $\mathrm{AO}$ plating. Figure $1 \mathrm{~b}-$ Infected nonunion of the forearm bones at 11 months. The radiograph shows CFRP plates applied in the 'bed' of the removed $A O$ plates after debridement. Figure lc - Radiographic appearance showing union of both bones after removal of CFRP plates at eight months.

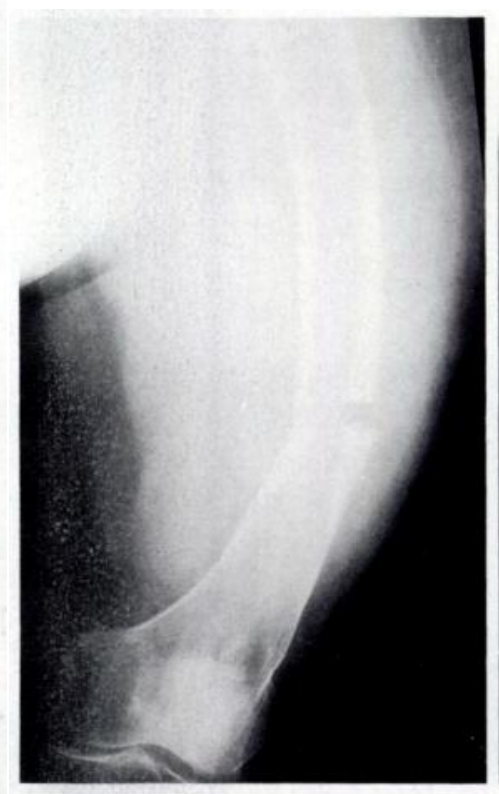

Fig. 3a

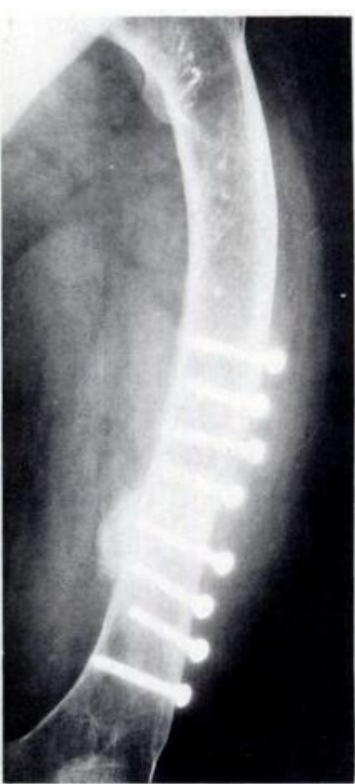

Fig. 3b

Figure 3a-Case 15. Mid-shaft fracture in a femur, of curved shape secondary to rickets with osteoporotic bone, in an 80-year-old woman. The radius of curvature was too great for an intramedullary nail. Figure $3 \mathrm{~b}$ - Union with abundant external callus opposite the plate at 16 


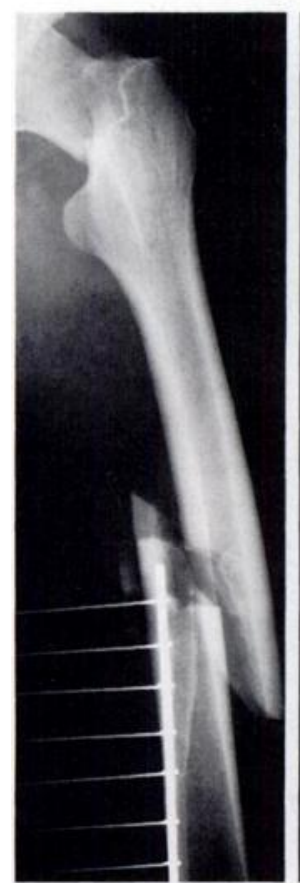

Fig. 4a

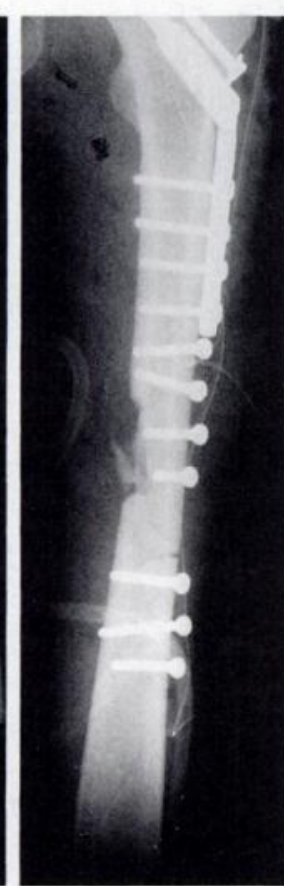

Fig. 4b

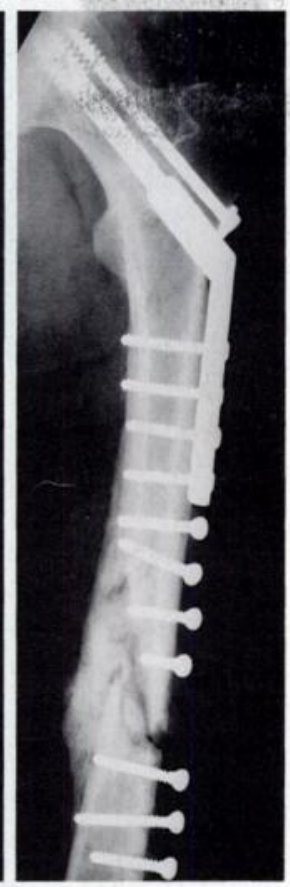

Fig. 4c
Figure 4a-Case 18. Basicervical and mid-shaft femoral fractures with medial comminution sustained in a high-speed motor-cycle accident. Figure $4 b$ - Internal fixation with a dynamic hip screw and CFRP plating. Figure $4 c-$ Both fractures united at 16 weeks, illustrating the abundant callus associated with the more elastic fixation and the gaps acceptable with this method. surrounding tissues. Specimens were embedded in paraffin wax and sections stained with haematoxylin and eosin, Goldner's trichrome, MSB (Martius scarlet blue), and Ralis tetrachrome (Rális and Rális 1975).

\section{RESULTS}

Radiological union with satisfactory clinical results was achieved in 18 of 19 patients within 40 weeks (Figs 1 to $5)$. In case 10 , there had been nonunion of radius and ulna for 12 years, despite six operations. After CFRP plating, the radius united but the ulna remained ununited. Despite this the patient had a satisfactory forearm and was content with the result.

Two other patients developed complications. In case 11 the screws became loose in porotic bone. At reoperation nuts were applied to the screws, similar to those shown in Figure 5. The bone then united within 20 weeks.

The only complete failure was case 19 . The patient had infected nonunion of the femur after treatment with a locking nail two years previously. A CFRP plate was applied after debridement. Postoperatively the infection did not recur, but full weight-bearing took place before a cast brace could be applied and the screws pulled out of the proximal end of the plate.

Histology. We studied a total of 17 biopsy specimens, seven from this series and a further ten from 'routine' fractures, after an average period of 16 months (4 to 30 ). A variable degree of fibrosis was found, with some occasional foreign-body granulation tissue around areas where some carbon fibres lay free on the periosteum. Small particles of carbon debris were seen within

Figure 5a-Case 12. A 69-year-old man had an infected nonunion of a tibial fracture at 25 months, despite sequestrectomies and debridements. The radiograph after CFRP plating and cancellous chip grafting shows nuts which were added because the bone was very porotic. Figure $5 b$ - Fracture consolidated at 12 months.

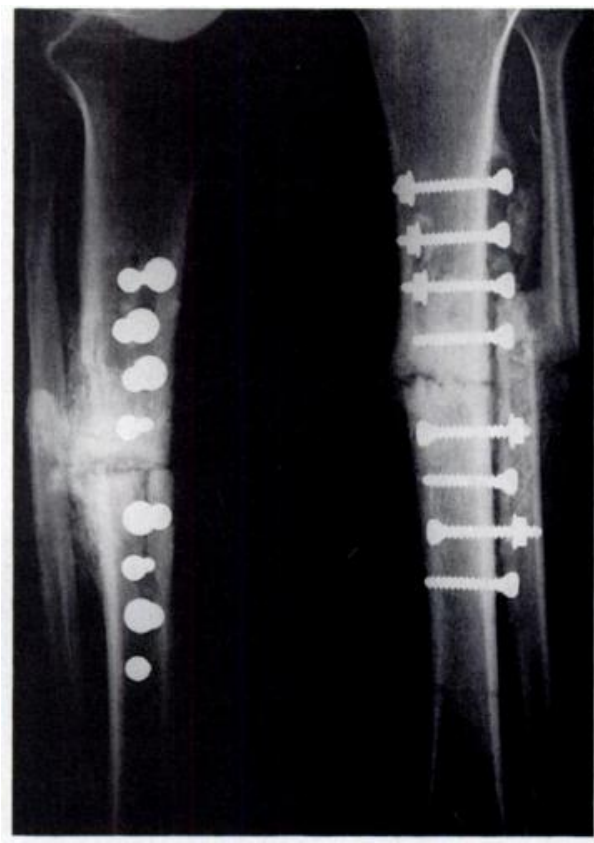

Fig. 5a

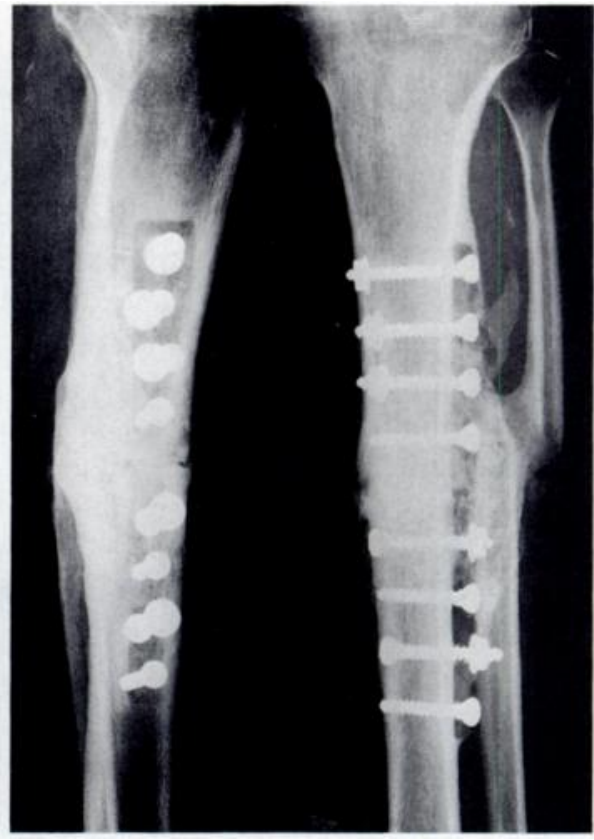

Fig. 5b 
histiocytes. More importantly, however, there was no evidence of any dysplastic or chronic inflammatory changes in any of the sections. Despite some tissue staining, we saw no macroscopic granulation tissue or evidence of the acute inflammatory reaction reported in $12.5 \%$ of cases by Ali et al (1990). However, this may reflect differences in the timing of the removal of the plates in the two series.

\section{DISCUSSION}

Our series of cases show that this form of fixation is well tolerated by the tissues, confirming previous reports of the use of carbon fibre and epoxy resin (Tayton, Philips and Ralis 1982; Howard, Taylor and Gibbs 1985). In all the comminuted fractures it was possible to avoid the use of supplementary bone grafts, an advantage particularly in the elderly. The technique was also simplified by leaving most of the fragments undisturbed in the knowledge that they would become bridged by callus. For the same reason gaps were accepted which would be unacceptable with rigid fixation.

In case 18 (Fig. 4), there was a segmental fracture of the shaft of the femur with comminution of the medial side. The current treatment would probably be with a reconstruction nail, but at the time, none was available. CFRP plating with no bone grafting resulted in abundant callus on the medial cortex diametrically opposite the plate (Fig. 4c).

Poor bone quality may be a contra-indication to the use of metal plates because of the tendency for the screws to loosen. There is then a race between this loosening and the advent of union, and any technique which accelerates union is therefore helpful. The use of flexible plates appears to speed up the formation of abundant external callus, providing additional stabilisation of the fracture within weeks.

This was well shown in case 16, a 75-year-old woman who sustained a comminuted supracondylar ' $T$ ' fracture of the femur. Three months of unsuccessful conservative treatment had reduced her already thin bones to the consistency of cheese. Despite this a specially contoured plate remained in position and external callus began to form within a few weeks. Cases 1 to $5,7,12$ and 13 behaved similarly.

Atrophic nonunion cannot be treated by internal fixation alone. Activity at the fracture has ceased and requires further osteogenic stimulus. It is usually recommended that internal fixation should be supplemented by cancellous grafts, but if the fixation is rigid, the combination is somewhat illogical. A bone graft will stimulate external callus formation: a rigid plate tends to inhibit it. In practice, this combination usually works, but it would be better to use a method of fixation which would also stimulate callus formation. This is well shown in our cases 9 to 14 .

Infection gives rise to particular problems in the presence of rigid fixation because of the prolonged healing time. The retention of the implant hinders the elimination of infection whereas its removal risks nonunion. The early development of callus with flexible plates allows earlier removal of the implant, as originally reported by Tayton et al (1982), and demonstrated in case 2 of our series.

This principle has been extended by one of us (DS) to the use of CFRP plates for open fractures as an alternative to external fixation. This gives easy access to the wound for subsequent care. Apart from the more rapid union it seems that CFRP plates may be better tolerated than their metal equivalents. Experimental work on sheep carried out in Cardiff (Johnson-Nurse, unpublished data, 1980) showed that when composite plates are used in open wounds, epithelialisation over the plate occurs in less than half the time of the equivalent metal plate. Our cases 2 and 6 support this observation.

Conclusions. While the use of metal plates and intramedullary nails remains the mainstay of internal fracture fixation, we have found CFRP plates particularly helpful in managing a number of difficult fractures. Currently, they cannot match their 'rigid' metal counterparts in terms of versatility, but they have been valuable when dealing with unusual problems.

No benefits in any form have been received or will be received from a commercial party related directly or indirectly to the subject of this article.

\section{REFERENCES}

Ali MS, French TA, Hastings GW, et al. Carbon fibre composite bone plates. J Bone Joint Surg [Br] 1990; 72-B:586-91.

Bradley JS, Hastings GW, Johnson-Nurse C. Carbon fibre reinforced epoxy as a high strength, low modulus material for internal fixation plates. Biomaterials $1980 ; 1: 38-40$.

Howard CB, Taylor KJJ, Gibbs A. The response of human tissues to carbon reinforced epoxy resin. J Bone Joint Surg [Br] 1985; 67 B:656-8.

McKibbin B. The biology of fracture healing in long bones. J Bone Joint Surg [Br] 1978; 60-B:150-62.

Müller ME, Allgöwer M, Schneider R, Willenegger H. Manual of internal fixation 3rd ed. Berlin, etc: Springer-Verlag, $1991: 1-2$.

Rális ZA, Rális HM. A simple method for the demonstration of osteoid in paraffin sections. Med Lab Technol 1975; 32:203-13.

Tayton K, Johnson-Nurse C, McKibbin B, Bradley J, Hastings G. The use of semi-rigid carbon-fibre reinforced plastic plates for fixation of human fractures. J Bone Joint Surg [ Br] 1982; 64-B:105-11.

Tayton K, Phillips G, Ralis Z. Long term effects of carbon fibre on soft tissues. J Bone Joint Surg [Br] 1982; 64-B:112-4. 